\title{
BATIK PRODUCT INNOVATION THROUGH COLOR THEORY IN DESIGN AS A FORM OF PRODUCT DIVERSIFICATION
}

\author{
Yunida SOFIANA*, Titi INDAHYANI, and Maryani MARYANI \\ Interior Design Department Schoolof Design, Bina Nusantara University Jakarta Indonesia \\ *ysofiana@binus.edu
}

\begin{abstract}
The purpose of Bina UMKM Batik is to provide training on the technique of mixing and matching (composition) colors, motifs and other materials (plastic) with batik waste produced by SMEs in order to produce batik products that are attractive in terms of color composition. As well as helping MSMEs in reducing the waste of batik cloth produced. The form of utilization of Batik waste will be the use of unused cloth from the rest of batik production which has been made in the form of patchwork in various sizes, colors and motifs characterized by Pekalongan batik. These materials will be designed by taking into account the type of product to be made, the materials used and the color composition to be used in the design of batik products such as bags, chair cushions and table ware sets. It is hoped that from this training, Batik SMEs can utilize the remaining batik cloth waste and reduce waste from existing batik and can produce product diversification that has design value and economic value. The process of making products will gradually be documented with videos so that MSMEs can follow how to produce products that have been designed. And product prototypes that have been made will be used as examples by MSMEs so that they can follow the design and quality standards of the products that have been made.
\end{abstract}

Keywords: Patchwork, Color Composition, Batik Waste, Batik Products, SMEs

\section{BACKGROUND}

The Pekalongan area is one of the batik industry areas in the northern coastal area of the island of Java, known as Coastal Batik. Pekalongan batik has its own characteristics when compared to other batik on the island of Java, including a variety of patterns with bolder and brighter colors. These bold and bright colors and motifs can be the main attraction of the batik cloth produced. The batik industry in Pekalongan produces batik cloth and printed batik cloth (stamp) which have been made into various finished products such as clothing, bags and other products.

One of the Pekalongan Batik Craftsmen who has a branch in the Jakarta area is Batik Likrik which is located in the East Jakarta area. Batik Likrik together with MSMEs in the Pekalongan area are currently competing to produce a variety of batik products that can compete with fellow batik industries to seize the existing market, but sometimes they have problems implementing designs into the batik products they produce so that the products they make sometimes the same as those on the market and do not feature a special design.

Sometimes in the process of making these batik products, they produce a lot of scraps of cloth which then increase and become waste in their batik production site. The Batik convection industry is one that produces a lot of scrap fabric that can be used to make products made from batik cloth. The remaining cloth from batik production can be reused to make new products by combining the remaining cloth with new materials or other materials. The products made will be mixed and matched with the size and color of the remaining batik cloth so that the new product is different from the existing product.

Based on the results of discussions with Batik SMEs, it can be concluded that the problems faced by batik SMEs, especially Likrik Batik, are the need to diversify products from batik cloth by making products that are different from existing ones and utilizing the batik waste they produce into useful products.

The solutions given to their problems are first, to design products that are different from the existing ones (product diversification) and introduce them to product design trends and needs in society so that the products they produce can reach a wider market. To help them develop existing product designs, batik SMEs need to know the procedures for using colors and other materials to mix and match with the motifs and colors of the batik cloth they make so that the products made are more varied in terms of color and material with different product functions.

The second solution is to utilize waste or leftover batik cloth from the batik industry in the Batik SMEs so that it can be used to make different products from existing ones by mixing and matching leftover batik with other fabric materials or other materials such as plastic. So, even though the remaining batik cloth is not too much, it can still be used by creating a design pattern that combines batik cloth with plain cloth or other materials such as plastic so that the cloth is waterproof so it does not need to be washed. The types of products that will be made in this training are bags, chair cushions and tableware sets.

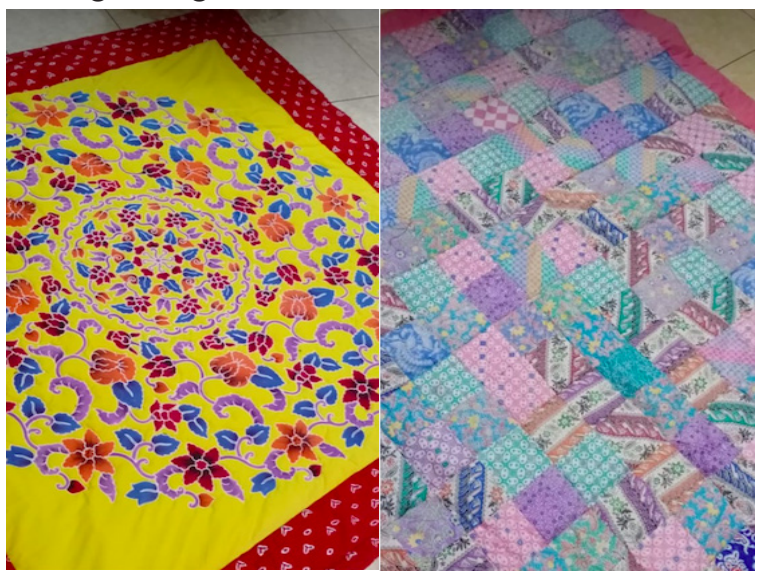

Picture 1. UMKM product Patchwork \& Quilting 
The design technique used is to make a pattern with a composition of colors and motifs according to the type of product to be made and use sewing techniques that are commonly used by MSME tailors such as patchwork and quilting techniques. With the creation of a new design pattern, it is hoped that it can become an alternative choice for consumers and attract interest from young people and increase the income of craftsmen, especially batik SMEs.

\section{METHOD}

The method of implementing this activity consists of stages of design, implementation, training and guidance and evaluation.

Design stage: at this stage, data is collected about the types of batik cloth waste in Pekalongan SMEs along with the motifs and colors that are commonly used. Processing of batik cloth waste is carried out by selecting a harmonious color composition. This design will be made in several alternatives as an option that will be produce and then give to SMEs. At this stage, the design is carried out by a lecturer from interior design by using color theory as a guide in arranging colors in batik into harmonious color composition. The color arrangement will be made using the technology or application such as app.prequilt. com . The technology or application will help the SME's to select the color and combine each color they have and help them to choose the harmonious composition color before they cut the fabric. The results of the arrangement of color and patterns will be made into products such as cushion, tableware and bag.

Implementation stage: at this stage, the color composition that has been made will be made into products in the form of bags, chair cushions and tableware sets. The arrangement of patterns and colors that have been made is then applied to the product designs of bags, chair cushions and tableware. Bags and tableware products will be varied with plastic as a coating. With the addition of plastic material as a coating, the product can look different. Due to the pandemic conditions that make it impossible to conduct training directly (face to face), the manufacture of products will be documented via video so that SMEs can follow suit.

Training and guidance stage: After product samples are made and documented with video, MSMEs can make these products and the results will be viewed through online media (zoom) so that training and guidance on color composition and manufacture is carried out via zoom. If there are questions from MSMEs about making color compositions and the process of making products, they can be done during the training and guidance.

Evaluation stage: at this stage, all products that have been made by SMEs will be evaluated by evaluating the batik waste used, the composition of colors made and the products produced. The product will be marketed to see if the market response to the product has been successful in diversifying the product.

\section{RESULTS AND DISCUSSION PEKALONGAN BATIK PATTERN}

Pekalongan batik is famous for the use of bright and bright colors in its batik, although there are also some batiks which are dominated by black, white, and brown colors. Bright and light colors are commonly used such as bright pinks, greens, yellows, reds and blues. In this training, the batik colors used are the colors of batik cloth obtained from the Pekalongan batik industry, namely green, red, black and brown (pictures $2 \& 3$ ). The batik cloth that will be made is in the form of pieces of cloth (patchwork) which will be connected to another sheet (patchwork). One sheet of fabric that has been connected (patchwork) can consist of several colors. The colors in the patchwork are a combination of different colors so that the patchwork looks attractive and the colors look harmonious.
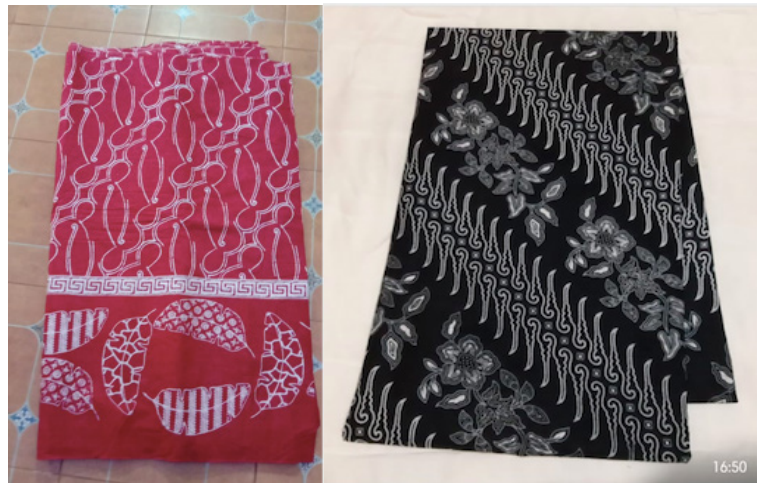

Picture 2. Pekalongan Batik Color (red and black)

\section{COLOR COMPOSITION THEORY}

To produce attractive and harmonious colors, in this training, MSMEs will be given training on how to make color compositions using the color wheel. The steps taken by MSMEs are choosing the batik cloth to be patchworked, then looking at the dominant color of the cloth and placing it on the color wheel. The color wheel has 3 primary colors, 3 secondary colors and 6 tertiary colors. Of the 12 colors, there will be many color derivatives that can be used as alternative colors for patchwork.

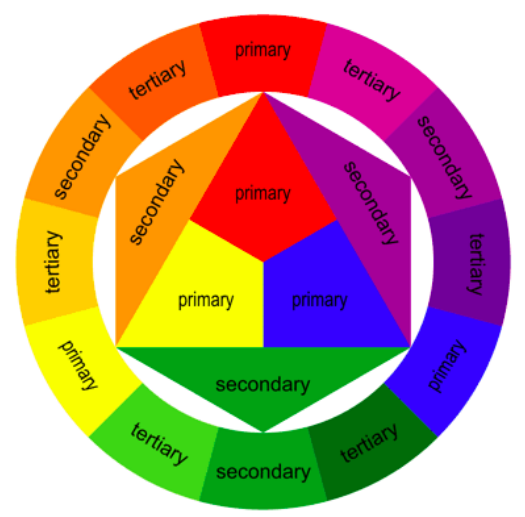

Picture 3. Color Wheel

Green color selection on the Color Wheel is a green color with adjacent color compositions, namely green to blue, green and green to brass. This close selection 
of colors in color theory is called Analogous (picture 4). The definition of Analogous in color wheel is opposite of contrasting colors, analogous colors stand next to each other on the color wheel, and they support each other when combined. Since they come from a similar place their transitions are gentle and the overall effect they give is one of harmony and balance.

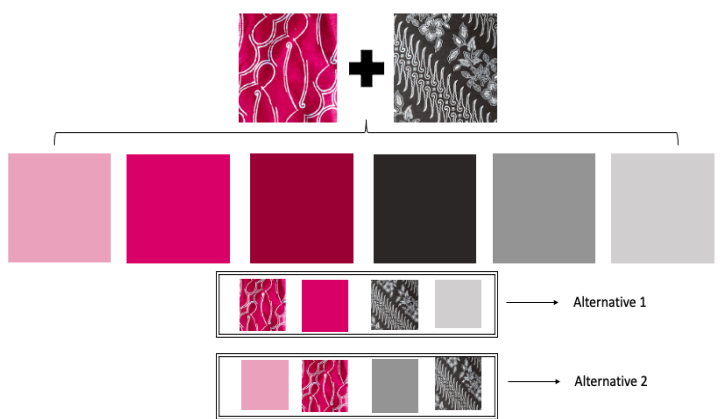

Picture 4. Combination of different Color selected from Batik

\section{CREATING COLOR COMPOSITION}

From the color choices on the color wheel, a fabric arrangement and connection (patchwork) are made in the form of a $5 \times 5$ module box to help arrange the colors and shapes that will be made. The color composition on the module is made of green batik color following the pattern that is usually made in the patchwork technique. As an alternative, several patterns are made to get several variations of patterns with different color compositions and shapes. The advantage of making patchwork using color composition is that the result of color arrangement that follows color theory can produce more attractive colors than patchwork that does not use color theory (picture 5).

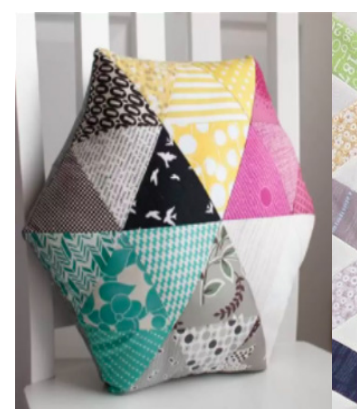

Composed color composition

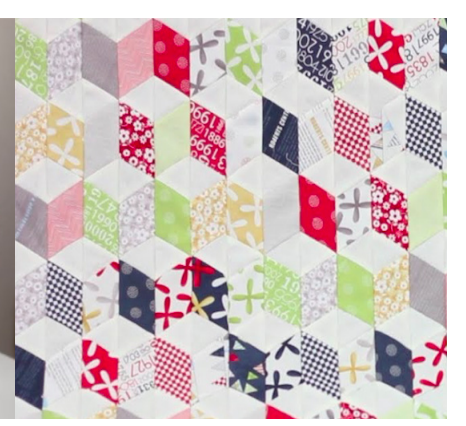

Color composition is not arranged
Picture 5. Examples of 2 Different Patchwork Color Composition

From the examples of the two patches above, it can be seen that arranging colors into an arrangement gives an attractiveness to the product that is made. Likewise, the results of the patchwork made by MSMEs above (picture 1) have not used the color arrangement in the products they make. So that training in making color arrangements using design color theory needs to be given so that the resulting product results are more varied and interesting.

Here is some composition of batik from picture 2 which combine 2 solid based color that will be created for UMKM's products.
1. Color composition for Bag
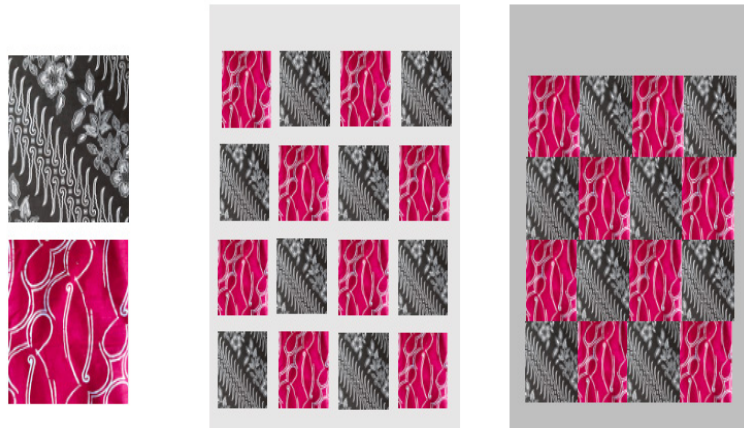

Picture 6. Color Composition from batik for bag

2. Color composition for Cushion
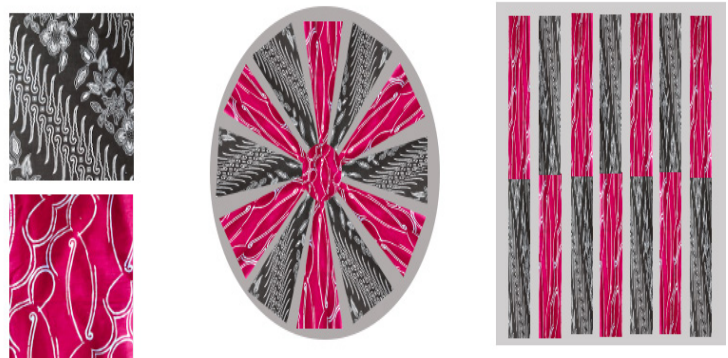

Picture 7. Color Composition for Batik for Cushion

3. Color composition for Tableware

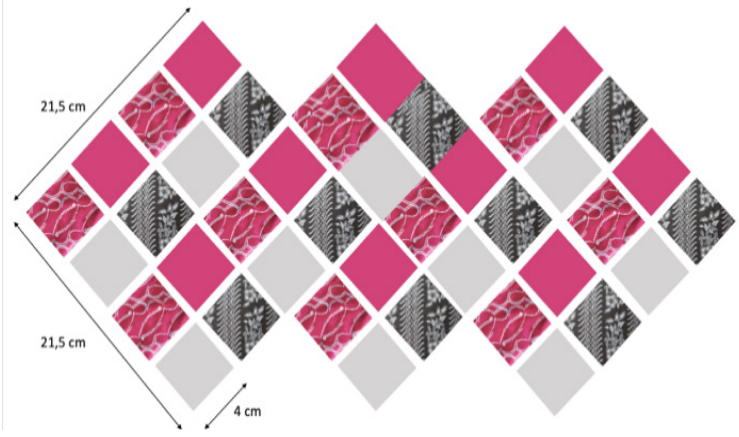

Picture 8. Color Composition for Batik for Tableware

4. Color composition for other shape.
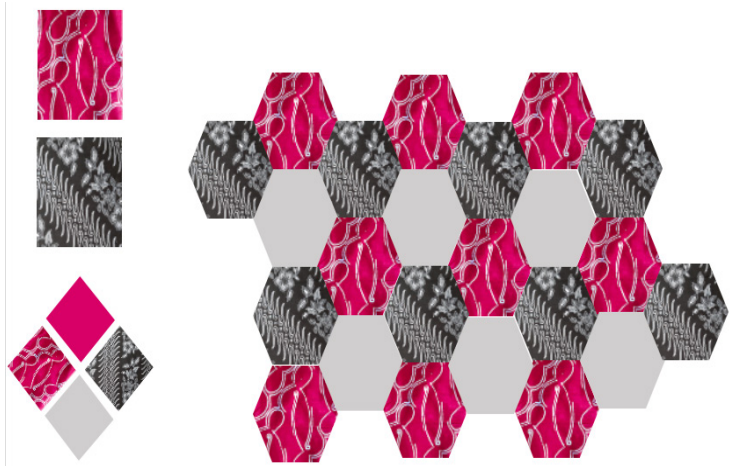

Picture 9. Other shape for color composition

\section{CONCLUSION}

Creative economic empowerment activities through diversification of Batik products using batik cloth waste can be carried out by MSMEs to survive during this pandemic. Product diversification needs to be done due 
to changing community needs and during this pandemic, batik products need to look at trends in the market for Batik needs and make design changes to attract buyers. By doing diversification through the color composition of batik material, it is hoped that the product will have variations in terms of color and material and that MSMEs can attract market interest with the new products produced. This community service report can be used as a reference to encourage the potential of MSMEs through the creative economy.

\section{REFERENCES}

https://www.sewingmachinesplus.com/sewblog/colortheory-quilters/ accessed 1 Juni 2021

https://patternobserver.com/2014/05/19/using-color-intextile-design/ accessed 1 Juni 2021 https://fitinline.com/article/read/7-cara-membuat-batikcap-dengan-mudah-dan-praktis/ accessed 1 Juni 2021

http://ciputrauceo.net/blog/2015/9/16/diversifikasi accessed 1 May 2021

https://keuangan.kontan.co.id/news/gunakan-strategidiversifikasi-investasi-selama-pandemi accessed 1 May 2021

https://www.startup4industry.id/e/produk-ikm-di-tengahpandemi accessed 1 May 2021

https://www.republika.co.id/berita/qmrx9g370/ diversifikasi-usaha-kunci-bertahan-di-tengahpandemi accessed 1 May 2021 